\title{
酛 New Disease Reports \\ Valeriana jatamansi as a new natural host of Bhendi yellow vein mosaic virus and Papaya leaf curl virus betasatellite from Northern India
}

\author{
D. Sharma ${ }^{1}$, S. Sharma ${ }^{2}$, N. Singh ${ }^{2}$ and V. Hallan ${ }^{1 *}$ \\ ${ }^{1}$ Plant Virology laboratory, CSIR-Institute of Himalayan Bioresource Technology, Palampur, Himachal Pradesh -176061, \\ India; ${ }^{2}$ Department of Chemistry and Biochemistry, Chaudhary Sarwan Kumar Himachal Pradesh Krishi Vishvavidyayala, \\ Palampur, Himachal Pradesh -176061, India \\ *E-mail: hallan@ihbt.res.in
}

Received: 31 Mar 2015. Published: 03 Aug 2015.

Valeriana jatamansi, a rhizomatous herb in the family Valerianceae, popularly known as Indian valerian, is found in all temperate and subtropical areas of the world. The herb is used in traditional Indian medicine and regarded as an aphrodisiac, antispasmodic, tranquiliser, antiseptic, expectorant, febrifuge, nerve tonic, ophthalmic and sedative. The essential oils of root extracts have antioxidant activity (Thusoo et al., 2014). During a survey in June 2014, V. jatamansi growing in a herbal garden in the CSIRIHBT campus, Palampur (Latitude: $32^{\circ} 7^{\prime} \mathrm{N}$; Longitude: $76^{\circ} 32^{\prime} \mathrm{E}$ ) was displaying crinkling of leaves (Fig.1) and whitefly infestation. Both of these features suggested begomoviral infection and attempts were made to detect the virus. To achieve this, total genomic DNA was subjected to rolling circle amplification (RCA) using the TempliPhi ${ }^{\mathrm{TM}}$ Amplification Kit (GE Healthcare, USA). The RCA product was subjected to PCR amplification using begomovirus specific degenerate primers 302 (5'-TGTGARGGYCCWTGYAARGTYCA-3') and 424 (5'-CARRTMMRRTTCAAYHACAACMTVMGGA-3'; Zaffalon et al., 2012). These primers amplified a fragment $\sim 850$ bp in size which contained partial sequences of virion DNA-A (Fig. 2a). Specific primers for betasatellite DNA (Briddon et al., 2002), amplified a $\sim 1.3 \mathrm{~kb}$ fragment (Fig. 2b). The $1.3 \mathrm{~kb}$ betasatellite and 850bp DNA-A amplicons were cloned and sequenced (GenBank Accession Nos. LN831956 and LN831955, respectively).

Analysis of the sequence data revealed that the DNA-A specific amplicon shared 93-99\% nucleotide sequence identity with several Bhendi yellow vein mosaic virus (BYVMV) isolates from Abelmoschus esculentus (Fig. 3). Okra is commonly known as bhendi in India and hence some Okra yellow vein mosaic isolates are also nominated as BYVMV. The $1367 \mathrm{bp}$ sequence of betasatellite DNA showed highest nucleotide identity (95\%) and closest phylogenetic relationship with Papaya leaf curl virus betasatellite isolate PaLCuB-Pumpkin: IARI (JX040472) reported from pumpkin (Cucurbita pepo) (Fig. 4). In order to assess the level and prevalence of virus infection on $V$. jatamansi, 80 samples from two locations (40 each) were collected. These samples were collected from plants randomly exhibiting mild or severe crinkling or no symptoms. Total DNA was extracted from the samples and tested for the presence of BYVMV by Southern blot hybridization (Sambrook et al., 1989) using a non-radioactive DIG labelled virus-specific probe (Roche, Germany). Results revealed that 32 of the 80 samples (40\%) tested positive for the virus.

To the best of our knowledge this is the first report of begomovirus associated DNA-A and betasatellite infection of $V$. jatamansi. Apart from A. esculentus, BYVMV has been found at sites distant from those described here in the deciduous shrub Litsea spp. (Roy et al., 2015). As V. jatamansi is present as a natural population, the presence of begomovirus and betasatellite DNA suggests that $V$. jatamansi may act as a reservoir for the virus with the potential to cause devastating diseases on vegetables.

\section{Acknowledgements}

The Directorand the CSIR-IHBT and CSIR network project "SIMPLE" are thankfully acknowledged. This is publication number 3841 .

\section{References}

Briddon RW, Bull SE, Mansoor S, Amin I, Markham PG, 2002. Universal primers for the PCR-mediated amplification of DNA $\beta$. Molecular Biotechnology 20, 315-318. http://dx.doi.org/10.1385/MB:20:3:315

Roy B, Chakraborty B, Mitra A, Sultana S, Sherpa AR, 2015. Natural occurrence of Bhendi yellow vein mosaic virus on Litsea spp. in India. New Disease Reports 31, 7. http://dx.doi.org/10.5197/j.2044-0588.2015.031.007

Sambrook J, Fritsch EF, Maniatis T,1989. Molecular cloning: A laboratory manual, 2nd edition, Volumes 1, 2 and 3. Cold Spring Harbor, NY, USA: Cold Spring Harbor Laboratory Press.

Thusoo S, Gupta S, Sudan R, Kour J, Bhagat S, Hussain R, Bhagat M, 2014. Antioxidant activity of essential oil and extracts of Valeriana jatamansi roots. BioMed Research International, 2014, Article ID 614187, 4 pages. http://dx.doi.org/10.1155/2014/614187

Zaffalon V, Mukherjee SK, Reddy VS, Thompson JR, Tepfer M, 2012. A survey of geminiviruses and associated satellite DNAs in the cottongrowing areas of northwestern India. Archives of Virology 157, 483-495. http://dx.doi.org/10.1007/s00705-011-1201-y

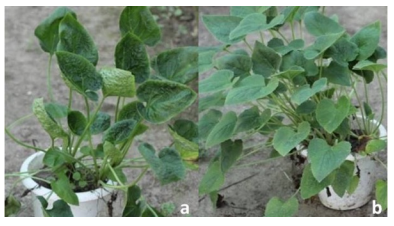

Figure 1

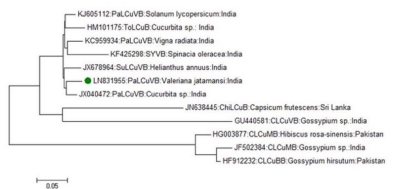

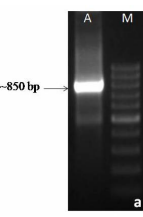

Figure 2
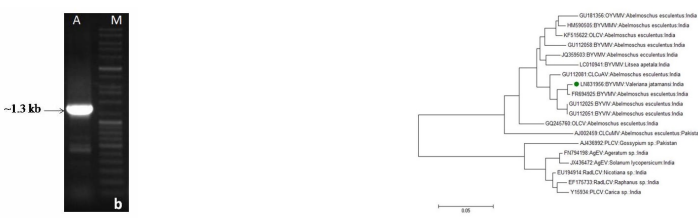

Figure 3

Figure 4

To cite this report: Sharma D, Sharma S, Singh N, Hallan V, 2015. Valeriana jatamansi as a new natural host of Bhendi yellow vein mosaic virus and Papaya leaf curl virus betasatellite from Northern India. New Disease Reports 32, 4.

http://dx.doi.org/10.5197/j.2044-0588.2015.032.004

(c) 2015 The Authors

This report was published on-line at www.ndrs.org.uk where high quality versions of the figures can be found.

New Disease Reports is a peer-reviewed on-line journal published by the British Society for Plant Pathology,

for more information visit http://www.ndrs.org.uk/ 